\title{
PERKEMBANGAN PENYULUHAN PERTANIAN DALAM MENDUKUNG PERTUMBUHAN PERTANIAN DI INDONESIA
}

\author{
Jufitra Vintarno$^{1}$, Yogi Suprayogi Sugandi ${ }^{2}$, Josy Adiwisastra ${ }^{3}$ \\ Program Pasca Sarjana Kebijakan Publik \\ Fakultas Ilmu Sosial dan Ilmu Politik \\ Universitas Padjadjaran \\ jufitra@yahoo.co.id ${ }^{1}$,yogi.suprayogi@unpad.ac.id²
}

\begin{abstract}
ABSTRAK
Penduduk pedesaan sebagian besar menggantungkan hidupnya melalui pertanian. Negara Indonesia merupakan negara yang memiliki lahan pertanian yang begitu luas. Berdasarkan data Badan Pusat Statistik tahun 2016, untuk lahan sawah di Indonesia mencapai 8,19 juta Ha. Data sensus penduduk menunjukkan jumlah penduduk pedesaan 50,21 \% (BPS, 2010). Dengan potensi yang besar di bidang pertanian, tentunya hal ini perlu dukungan sumber daya penyuluh pertanian yang unggul untuk mendukung program pemerintah dibidang pertanian. Setelah terbitnya Undang-Undang No. 23 Tahun 2014 Tentang Pemerintah Daerah muncul kekhawatiran mengenai eksistensi penyuluhan di Indonesia. Tujuan dari jurnal ini yaitu, memaparkan perkembangan penyuluhan pertanian dan bagaimana dukungan Undang-Undang No. 23 Tahun 2014 terhadap penyelenggaraan penyuluhan. Adapun metode yang digunakan yaitu studi pustaka bersumber dari jurnal, peraturan-peraturan dan artikel yang berkaitan dengan kebijakan penyuluhan pertanian. Hasil dari jurnal ini yaitu menunjukkan bahwa adanya perubahan paradigma penyuluhan setelah terbitnya Undang-Undang No. 23 Tahun 2014 Tentang Pemerintah Daerah.
\end{abstract}

Kata kunci: Penyuluhan pertanian, pertanian, kebijakan.

\begin{abstract}
Most rural communities depend their lives on agriculture. Indonesia is a country that has extensive agricultural land. Based on data from the Central Statistics Agency in 2016, rice fields in Indonesia reached 8.19 million hectares. Population census data shows the rural population of 50.21\% (BPS, 2010). With great potential in agriculture, of course this needs the support of superior agricultural extension resources to support government programs in agriculture. After the issuance of Law No. 23 of 2014 on Regional Governments, concerns arise about the existence of agricultural extension in Indonesia. The purpose of this journal is to spread the development of agricultural extension and how the position of Law No. 23 of 2014 on the implementation of agricultural extension. The methods used are library studies sourced from journals, regulations and articles relating to agricultural extension policies. The results of this journal show that there is a change in the agricultural extension paradigm after the issuance of Law No. 23 of 2014 on Regional Governments.
\end{abstract}

Keywords: agricultural extension, agriculture, policy

\section{PENDAHULUAN}

Negara Indonesia merupakan negara yang memiliki lahan pertanian yang begitu luas. Berdasarkan data Badan Pusat Statistik tahun 2016, untuk lahan sawah di Indonesia mencapai 8,19 juta Ha. Data sensus penduduk menunjukkan jumlah penduduk pedesaan 50,21 \% (BPS, 2010). Pengertian pertanian menurut Undang-Undang No. 16 Tahun 2006 Tentang Sistem Penyuluhan Pertanian, Perikanan, dan Kehutanan (UU SP3K) adalah seluruh kegiatan yang meliputi usaha hulu, usaha tani, agroindustri, pemasaran, dan jasa penunjang pengelolaan sumber daya alam hayati dalam agroekosistem yang sesuai dan berkelanjutan, dengan bantuan teknologi, modal, tenaga kerja, dan manajemen untuk mendapatkan manfaat sebesar-besarnya bagi kesejahteraan masyarakat.

Dalam kaitannya dengan pertanian, penduduk pedasaan sebagian besar menggantungkan hidupnya melalui pertanian. Dengan potensi yang besar di bidang pertanian, tentunya hal ini perlu dukungan sumber daya penyuluh pertanian yang unggul untuk mendukung program pemerintah dibidang pertanian serta mampu mendorong dan membantu petani agar merubah kehidupan petani menjadi sejahtera. Secara umum, jasa penyuluhan pertanian seharusnya berkontribusi terhadap perbaikan mata pencaharian untuk semua kelompok petani serta untuk meningkatkan produksi 
pertanian suatu negara secara keseluruhan termasuk penyediaan devisa dari ekspor produk pertanian (R. Haug, 1999). Penyuluhan pertanian tidak hanya berkaitan dengan masalah teknis di lapangan, tetapi memiliki peran dalam mendukung kehidupan sosial masyarakat yang adil dan sejahtera. Penyuluh pertanian sebagai aktor di lapangan harus menjalankan tugas dan fungsi sesuai dengan aturan yang berlaku. Penyuluh Pertanian Lapangan (PPL) secara langsung berinteraksi dengan petani atau masyarakat dan hampir seluruh aktivitas PPL ini berada di lapangan.

Dunia penyuluhan di Indonesia mengalami pasang surut yang cukup dinamis dari waktu ke waktu. Semenjak dibangun pada awal 1970-an, satu momentum penting sehingga kelembagaan penyuluhan mulai menata diri dengan baik adalah lahirnya UndangUndang No. 16 Tahun 2006 tentang Sistem Penyuluhan Pertanian, Perikanan, dan Kehutanan. Salah satu poin penting dalam Undang-Undang ini adalah perlunya membangun kelembagaan penyuluhan di daerah pada level provinsi maupun kabupaten/kota (Syahyuti, 2016). Lebih lanjut, setelah adanya Undang-Undang No. 23 Tahun 2014 Tentang Pemerintah Daerah, dianggap mempengaruhi bahkan mengancam keberadaan penyuluhan karena tidak mengakomodasi penyuluhan pertanian secara jelas. Oleh karena itu tujuan dari studi ini untuk memaparkan perkembangan penyuluhan pertanian dalam mendukung pertumbuhan pertanian di Indonesia terkait dengan UU SP3K.

\section{TINJAUAN PUSTAKA}

Penyuluhan pertanian di Indonesia telah mempunyai sejarah yang cukup panjang, yang dimulai sejak awal abad 20. Penyuluhan pertanian bermula dari adanya kebutuhan untuk meningkatkan hasil pertanian, baik untuk kepentingan penjajah maupun untuk memenuhi kebutuhan pribumi. Kebutuhan peningkatan produksi pertanian diperhitung-kan akan dapat dipenuhi seandainya teknologi-teknologi maju yang ditemukan para ahli dapat dipraktekkan oleh para petani sebagai produsen primer. Dengan hasil yang cukup menggembirakan, usaha-usaha ini terus dikembangkan dan kemudian dibentuk suatu sistem penyuluhan pertanian yang melembaga di Indonesia dengan dibentuknya Dinas Penyuluhan (Landbouw Voorlichting Dients atau LVD) pada tahun 1908 di bawah Departemen Pertanian (BPLPP, 1978; Iskandar, 1969 dalam Dwi Sadono,2008).

Penyuluhan pertanian mempunyai pengertian yaitu proses pembelajaran bagi pelaku utama serta pelaku usaha agar mereka mau dan mampu menolong dan mengorganisasikan dirinya dalam mengakses informasi pasar, teknologi, permodalan, dan sumber daya lainnya, sebagai upaya untuk meningkatkan produktivitas, efisiensi usaha, pendapatan, dan kesejahteraannya, serta meningkatkan kesadaran dalam pelestarian fungsi lingkungan hidup (Peraturan Menteri Pertanian Republik Indonesia No. 03 Tahun 2018 Tentang Pedoman Penyelenggaraan Penyuluhan Pertanian).

Jumlah tenaga penyuluh pertanian di Indonesia masih belum ideal dan belum sesuai dengan amanat UU Nomor 19 Tahun 2013 tentang Perlindungan dan Pemberdayaan Petani. Tercatat dari 72.000 desa yang berpotensi di bidang pertanian, baru tersedia 44.000 tenaga penyuluh pertanian. Seharusnya setiap desa itu satu penyuluh pertanian. Jumlah tenaga penyuluh yang berstatus pegawai negeri sipil saat ini mencapai 25.000 orang, sedangnya yang bersatus Tenaga Harian LepasTenaga Bantu Penyuluh Pertanian (THL-TBPP) berjumlah 19.000 orang. Dari 44.000 tenaga penyuluh itu, 32.000 diantaranya yang bersentuhan langsung dengan petani di lapangan. Penyuluh yang ada di tingkat kabupaten, kecamatan, dan desa, yang bersentuhan itu di tingkat desa. Mereka yang menangani 72.000 desa potensi pertanian di Indonesia. Secara rerata, seorang penyuluh harus menangani petani di tiga desa sehingga membuat pendampingan tidak berlangsung efektif dan optimal (Momon Rusmono dikutip Syaifudin, 2017).

Merekrut atau mengadakan tenaga penyuluh pertanian sangat penting dalam melakukan penyuluhan kepada kelompok tani karena hal itu yang mereka butuhkan, dan secara tidak langsung keberadaan penyuluh dapat merubah perilaku petani untuk mencapai swasembada pangan di Indonesia (Pricylia et al, 2018)

Perlu dilakukan pengembangan potensi sumber daya manusia penyuluh pertanian. Komponen pengembangan sumber daya manusia (SDM) adalah: (1) learning, proses di mana seseorang memperoleh dan mengembangkan pengetahuan, keterampilan, kemampuan, perilaku dan sikap. Ini melibatkan modifikasi perilaku melalui pengalaman serta metode yang lebih formal untuk membantu orang belajar di dalam atau di luar tempat kerja; (2) development, pertumbuhan atau perwujudan kemampuan dan potensi seseorang melalui penyediaan pengalaman belajar dan pendidikan; (3) training, aplikasi sistematis dari proses formal untuk menanamkan pengetahuan dan membantu orang untuk memperoleh keterampilan yang diperlukan bagi mereka untuk melakukan pekerjaan mereka secara memuaskan; dan (4) education, pengembangan pengetahuan, nilai-nilai dan pemahaman yang diperlukan dalam semua aspek kehidupan daripada pengetahuan dan keterampilan yang berkaitan dengan bidang-bidang kegiatan tertentu (Armstrong dan Taylor, 2013:284).

Perjalanan pengembangan penyuluhan pertanian sejak dulu mengalami pasang surut dan liku-liku yang dinamik sesuai dengan perkembangan zaman dan berperan penting dalam pembangunan pertanian yang merupakan bagian dari pembangunan nasional serta merupakan proses transformasi dari pertanian 


\section{Perkembangan Penyuluhan Pertanian Dalam Mendukung Pertumbuhan Pertanian Di Indonesia (Jufitra Vintarno, Yogi Suprayogi Sugandi, Josy Adiwisastra)}

tradisional menjadi pertanian tangguh yang mampu memanfaatkan sumber daya secara optimal, mampu melakukan penyesuaian diri dalam pola dan struktur produksinya terhadap perubahan sikap, perilaku, pengetahuan dan keterampilan petani dan keluarganya sebagai hasil dari proses belajar mengajar (Sundari. et al, 2015).

Penyuluhan pertanian diakui sebagai instrumen utama untuk meningkatkan produktivitas pertanian dan pendapatan pertanian, sangat sedikit perhatian yang diberikan pada formulasi, konten, dan implikasi dari kebijakan penyuluhan tersebut, atau apa yang harus diantisipasi dimasa yang akan datang (Jiggins dalam $\mathrm{J}$. A. Coutts, 1995). Sebelum adanya UU SP3K, keberadaan kelembagaan penyuluhan di Indonesia berada di bawah Bimbingan Massal. Hingga pada puncaknya pada tahun 1984 Indonesia pencapaian swasembada beras merupakan suatu catatan penting.

Sejalan dengan pelaksanaan otonomi daerah, otoritas penyuluhan pertanian juga telah didelegasikan dari pemerintah pusat kepada pemerintah daerah tingkat kabupaten. Subejo dalam Mawardi (2004) mengidentifikasi kendala yang dihadapi oleh penyuluhan pertanian era otonomi daerah: (1) adanya perbedaan pandangan antara pemerintah daerah dan anggota DPRD dalam memahami penyuluhan pertanian dan perannya dalam pembangunan pertanian, (2) kecilnya alokasi anggaran pemerintah daerah untuk kegiatan penyuluhan pertanian, (3) ketersediaan dan dukungan informasi pertanian sangat terbatas, (4) makin merosotnya kemampuan manajerial penyuluh.

Pada bulan Oktober 2006, telah diundangkan UU Nomor 16/2006 tentang SP3K. Salah satu amanat UU tersebut adalah pembentukan kelembagaan penyuluhan pada berbagai level administrasi pemerintahan, selain itu pemerintah daerah harus berkontribusi terhadap pendanaan kelembagaan dan operasionalisasinya.

\section{METODOLOGI}

Metode yang penulis gunakan dalam jurnal ini adalah deskriptif, analisis teknik pengumpulan data bersumber dari jurnal, peraturan-peraturan dan artikel yang berkaitan dengan kebijakan penyuluhan pertanian.

\section{PEMBAHASAN}

\section{Tujuan Dan Sasaran Penyuluhan Pertanian}

Penyuluhan pertanian dapat dikatakan sebagai ilmu sosial yang mempelajari sistem serta proses perubahan yang terjadi pada individu dan masyarakat supaya terwujud perubahan yang jauh lebih baik dalam bidang pertanian. Penyuluh pertanian di Indonesia telah ada sejak jaman kolonial Belanda hingga saat ini. Seperti yang dijelaskan dalam UU SP3K, penyuluhan diselenggarakan berasaskan demokrasi, manfaat, kesetaraan, keterpaduan, keseimbangan, keterbukaan, kerja sama, partisipatif, kemitraan, berkelanjutan, berkeadilan, pemerataan dan bertanggung jawab.

Adapun Tujuan pengaturan sistem penyuluhan meliputi pengembangan sumber daya manusia dan peningkatan modal sosial, yaitu:

a. Memperkuat pengembangan pertanian yang maju dan modern dalam sistem pembangunan yang berkelanjutan;

b. Memberdayakan pelaku utama dan pelaku usaha dalam peningkatan kemampuan melalui penciptaan iklim usaha yang kondusif, penumbuhan motivasi, pengembangan potensi, pemberian peluang, peningkatan kesadaran, dan pendampingan serta fasilitasi;

c. Memberikan kepastian hukum bagi terselenggaranya penyuluhan yang produktif, efektif, efisien, terdesentralisasi, partisipatif, terbuka, berswadaya, bermitra sejajar, kesetaraan gender, berwawasan luas ke depan, berwawasan lingkungan, dan bertanggung jawab yang dapat menjamin terlaksananya pembangunan pertanian;

d. Memberikan perlindungan, keadilan, dan kepastian hukum bagi pelaku utama dan pelaku usaha untuk mendapatkan pelayanan penyuluhan serta bagi penyuluh dalam melaksanakan penyuluhan; dan

e. Mengembangkan sumber daya manusia, yang maju dan sejahtera, sebagai pelaku dan sasaran utama pembangunan pertanian.

Selain itu, sasaran pemerintah dalam penyuluhan pertanian yang paling berhak memperoleh manfaat penyuluhan meliputi sasaran utama dan sasaran antara. Sasaran utama penyuluhan yaitu pelaku utama dan pelaku usaha. Sasaran antara penyuluhan yaitu pemangku kepentingan lainnya yang meliputi kelompok atau lembaga pemerhati pertanian serta generasi muda dan tokoh masyarakat.

Dalam konteks penyuluh pertanian, pada era saat ini kegiatan penyuluhan tidak hanya satu arah. Penyuluh harus bisa hidup di antara petani, hadir di dalam semangat petani serta terlibat secara partisipatif dalam kegiatan petani. Jadi, penyuluh tidak hanya memberikan teori budidaya serta masalah hama dan penyakit tanaman, namun harus bisa membukakan dan menguatkan petani untuk berkarya (Syahyuti, 2014).

Tujuan dan sasaran penyuluhan pertanian sangat jelas untuk pertanian di Indonesia. Pemberdayaan petani hingga mampu memenuhi kebutuhan hidupnya dan memberikan perlindungan hukum dan keadilan menjadi point penting yang juga diperhatikan pemerintah. Aspek sosial dalam perlindungan dan keadilan diimplementasikan oleh lembaga atau Dinas terkait serta PPL. Melalui PPL sebagai ujung tombak, dalam interaksinya kepada petani harus mampu memberikan keadilan. Misalnya, dalam melaksanakan kunjungan atapun rapat kelompok tani, penyuluh harus memberikan informasi, edukasi dan advokasi yang benar kepada semua petani tanpa pandang bulu. 
Kebijakan pemberian bantuan dari pemerintah (pupuk atau alat mesin pertanian), penyuluh membantu petani dalam mengajukan permintaan bantuan tersebut kepada pemerintah daerah dan pemerintah pusat melalui dinas pertanian. Implikasinya jika hal tersebut tidak dilakukan dengan baik maka akan menimbulkan gesekan baik anatara penyuluh dan petani maupun antar petani itu sendiri.

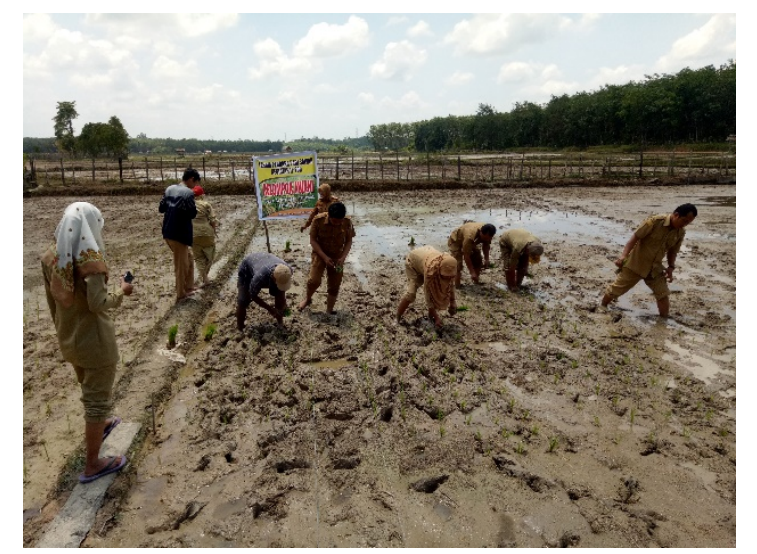

Foto 1: Penyuluh terlibat langsung dalam kegiatan tanam perdana padi sawah.

\section{Penyuluhan Pertanian Sebagai Kebijakan Jangka Pendek Dan Jangka Panjang}

Penyuluh pertanian merupakan ujung tombak dalam pembangunan pertanian. Penyuluh bersentuhan langsung dengan masyarakat yang secara tugas dan fungsi menyampaikan informasi ataupun edukasi yang relevan kepada petani. Untuk mencapai keberhasilan penyuluhan dibutuhkan tenaga pnyuluh yang baik secara kualitas maupun kuantitas. Dengan keadaan Indonesia yang memiliki lahan pertanian yang luas, penyuluhan pertanian tetap akan memegang peran strategis dalam keberhasilan pertanian. Selain itu, pemerintah harus mencari cara untuk mengedukasi petani dalam pembangunan pertanian, karena banyak petani di indonesia masih berpendidikan rendah dan memasuki usia senja.

Tujuan penyuluhan jangka pendek yaitu menumbuhkan perubahan-perubahan dalam diri petani yang mencakup tingkat pengetahuan, kecakapan, kemampuan, sikap, dan motivasi petani terhadap kegiatan usaha tani yang dilakukan. Tujuan penyuluhan jangka panjang yaitu peningkatan taraf hidup masyarakat tani sehingga kesejahteraan hidup petani terjamin. Tujuan pemerintah terhadap penyuluhan pertanian adalah: meningkatkan produksi pangan, merangsang pertumbuhan ekonomi, meningkatkan kesejahteraan keluarga petani dan rakyat desa, mengusahakan pertanian yang berkelanjutan.

Adapaun kebijakan penyuluhan pertanian seperti yang di atur dalam Permentan No. 3 Tahun 2018 dilakukan secara terintegrasi dengan program pembangunan pertanian untuk mewujudkan kedaulatan pangan dan kesejahteraan petani melalui pendekatan kawasan pertanian. Kebijakannya meliputi: a) pengembangan kemitraan dalam penyelenggaraan Penyuluhan Pertanian untuk penguatan Kelembagaan Penyuluhan Pertanian, Kelembagaan Petani, dan Kelmbagaan Ekonomi Petani; b) peningkatan nilai tambah dan daya saing produk Pertanian melalui keterpaduan sistem agribisnis hulu-hilir, teknologi tepat guna, dan teknologi informasi; c) fasilitasi pengembangan kemandirian dan profesionalisme Penyuluh Pertanian melalui peningkatan kompetensi profesi, dan lembaga sertifikasi profesi; dan d) pemenuhan prasarana, sarana, dan pembiayaan penyelenggaraan Penyuluhan Pertanian.

\section{Kekhawatiran Eksistensi Penyuluhan Pasca Terbitnya No. 23 Tahun 2014 Tentang Pemerintah Daerah}

Implementasi UU Otonomi Daerah berdampak pada penyelenggaraan penyuluhan pertanian menjadi berjalan dengan baik. Terkait dengan penyuluhan pertanian, sistem kelembagaan dan sistem tata kerjanya juga mengalami perubahan dengan pola yang tidak jelas. Ketika era Bimbingan Massal, penyuluh di lapangan yang langsung bersentuhan dengan petani memiliki home base di Balai Penyuluhan Pertanian, namun sejak tahun 1990-an (Surat Keputusan Bersama Menteri pertanian dan Menteri Dalam Negeri yang menyerahkan urusan penyuluhan kepada pemerintah kabupaten/kota) kelembagaan menjadi tidak jelas bahkan banyak yang dibubarkan. Terkait dengan kompetensi, orientasi berubah-ubah dari tuntutan kompetensi tunggal misalnya tanaman pangan (monovalen) menjadi kompetensi plural (polivalen). Setelah beberapa waktu, tuntutan kompetensi juga dikembalikan lagi ke monovalen. Masa-masa suram pembangunan pertanian dan lebih khusus lagi penyuluhan pertanian telah berdampak pada stagnasi produksi pertanian. Hal ini juga telah medorong pemerintah Pusat dan DPR untuk merancang undang-undang penyuluhan pertanian. Setelah melalui pembahasan panjang dan melelahkan, akhirnya pada tanggal 18 Oktober 2006 telah diundangkan UU Nomor 16/2006 tentang SP3K. Dengan adanya UU SP3K ini, penyuluhan pertanian lebih fokus, dan hal ini tentunya berdampak pada kehidupan sosial petani di Indonesia.

Setelah itu, pada tahun 2014 pemerintah mengeluarkan UU No. 23 tentang pemerintah daerah. Sebagian pihak memaknai negatif UU Pemda ini, namun sebagian pihak melihat sesungguhnya inilah kesempatan untuk memperkokoh keberadaan kelembagaan penyuluhan pertanian daerah. Dalam UU No. 23 tahun 2014, penyuluhan perikanan dikembalikan ke pusat, penyuluhan kehutanan ke provinsi, sedangkan penyuluhan pertanian menjadi tanggung jawab semua level secara konkurensi. Secara yuridis, UU No. 23 Tahun 2014 akan memperkuat keberadaan kelembagaan 


\section{Perkembangan Penyuluhan Pertanian Dalam Mendukung Pertumbuhan Pertanian Di Indonesia (Jufitra Vintarno, Yogi Suprayogi Sugandi, Josy Adiwisastra)}

penyuluhan pertanian karena sejalan dengan UU No. 16 Tahun 2006 tentang Sistem Penyuluhan Pertanian, Perikanan, dan Kehutanan. Dengan kata lain, kebijakan ini pada hakikatnya sejalan dan harmonis satu sama lain (Syahyuti, 2016). Hal ini juga didukung oleh UU No. 23 Tahun 2014 tentang Pemda yang juga mendukung azas hukum ini. Pasal 231 berbunyi "Dalam hal ketentuan peraturan perundang-undangan memerintahkan pembentukan lembaga tertentu di Daerah, lembaga tersebut dijadikan bagian dari Perangkat Daerah yang ada setelah dikonsultasikan kepada Menteri dan menteri yang menyelenggarakan Urusan Pemerintahan bidang pendayagunaan aparatur Negara”.

Pendirian kantor penyuluhan pertanian di daerah sesungguhnya telah didukung kebijakan yang kuat karena penyuluhan pertanian telah memiliki UU sendiri, yakni UU No. 16 Tahun 2006. Dalam konteks perbandingan hukum seperti ini, UU No. 16 Tahun 2006 merupakan lex specialis, artinya lebih tinggi dibandingkan UU No. 23 Tahun 2014 yang lex generalis. Pada Pasal 63 ayat (2) KUHP disebutkan bahwa "lex specialis derogat legi generali" adalah asas penafsiran hukum yang menyatakan bahwa hukum yang bersifat khusus (lex specialis) mengesampingkan hukum yang bersifat umum (lex generalis) (Syahyuti, 2016).

Untuk memperkuat sistem kelembagaan dan penyelenggaraan penyuluhan pertanian, pemerintah mengeluarkan Peraturan Menteri Pertanian Republik Indonesia No. 03 Tahun 2018 Tentang Pedoman Penyelenggaraan Penyuluhan Pertanian. Peraturan Menteri ini dimaksudkan sebagai acuan penyelenggaraan Penyuluhan Pertanian untuk pengelola Kelembagaan Penyuluhan Pertanian Pemerintah, Swasta, dan Swadaya, serta instansi terkait dalam penyelenggaraan Penyuluhan Pertanian, mulai dari pusat, daerah provinsi, daerah kabupaten/kota, kecamatan, dan kelurahan/desa serta pemangku kepentingan lainnya.

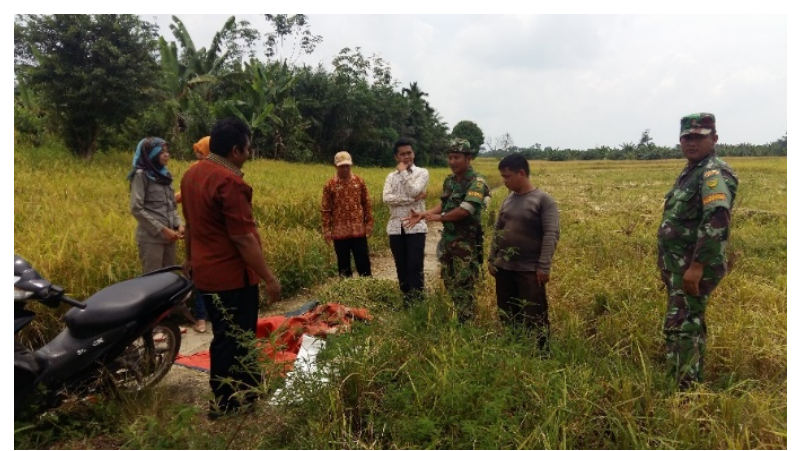

Foto 2 : Penyuluh dan Bintara Pembina Desa berkoordinasi membantu petani untuk kegiatan panen padi.

\section{Kesesuaian Sasaran Dan Tujuan Serta Masalah Yang Ada}

Tujuan dan sasaran kebijakan penyuluhan pertanian mencakup pelaku utama dan pelaku usaha. Dimana tujuan akhir pemerintah yaitu peningkatan pemberdayaan petani sehingga menjadi sejahtera dan meningkatkan produksi pertanian. Setiap target grup menjalankan perannya masing masing sesuai dengan kapasitas dan wewenangnya. Selain itu adanya kesetaraan kepada seluruh petani di Indonesia. Dalam implementasi kebijakan penyuluhan pertanian, masih terdapat permasalahan yang harus diperhatikan pemerintah.

1. Kualitas dan jumlah SDM penyuluh

Kualitas SDM penyuluh rendah menjadi salah satu permasalahan. Ketidakmampuan penyuluh dalam menjalankan program dari pemerintah dan minimnya disiplin ilmu yang dimiliki menjadi kendala dalam penyuluhan. Selain itu, proses adaptasi penyuluh yang kurang baik dalam masyarakat akan menimbulkan gesekan sosial di lingkungan masyarakat itu sendiri.

Kurangnya jumlah penyuluh serta sebaran penyuluh yang tidak merata. Keberadaan suatu daerah yang terpencil, minimnya saran dan prasarana serta jauh dari pusat kota menjadi salah satu alasan kurangnya jumlah penyuluh disuatu daerah tersebut. Idealnya 1 desa 1 penyuluh agar penyuluhan pertanian dapat berjalan baik. Dengan kondisi seperti ini pemerintah bisa berupaya menumbuhkembangkan penyuluh swadaya.

2. Sarana dan prasarana penyuluhan

Dengan keberadaan penyuluhan yang langsung bersentuhan dengan petani, tentunya membutuhkan sarana dan prasaran yang memadai. Pada prakteknya, masih banyak penyuluh yang belum mendapatkan sarana dan prasarana tersebut. Kondisi ini akan berpengaruh pada kinerja penyuluh dalam menjalankan aktivitasnya.

3. Mobilisasi dan perpindahan penyuluh

Motivasi dan semangat penyuluh dalam melakukan berbagai aktivitas penyuluhan dapat menentukan keberhasilan petani ataupun kelompok tani. Tekanan dan masalah sosial lainnya mempengaruhi mobilisasi penyuluh. Kebijakan dilakukan dinas terkait dalam merotasi atau melakukan pemindahan PPL dari satu desa pindah ke desa yang lain akan memberikan pengaruh sosial terhadap petani atau masyarakat. Adapula ketidaksesuian penyuluh atau petani terhadap kondisi seperti ini.

\section{KESIMPULAN}

Kebijakan penyuluhan pertanian mengacu kepada Undang-Undang Nomor 16 Tahun 2006 tentang Sistem Penyuluhan Pertanian, Perikanan, dan 
Kehutanan dan Peraturan Menteri Pertanian Nomor 03 Tahun 2018 tentang Pedoman Penyelenggaraan Penyuluhan Pertanian. Penyuluhan pertanian adalah proses pembelajaran bagi pelaku utama serta pelaku usaha agar mereka mau dan mampu menolong dan mengorganisasikan dirinya dalam mengakses informasi pasar, teknologi, permodalan, dan sumberdaya lainnya, sebagai upaya untuk meningkatkan produktivitas, efisiensi usaha, pendapatan, dan kesejahteraannya, serta meningkatkan kesadaran dalam pelestarian fungsi lingkungan hidup. Keberadaan UU No. 23 Tahun 2014 Tentang Pemerintah Daerah mendukung keberadaan kelembagaan penyuluhan pertanian di daerah. Urusan penyuluhan pertanian memang tidak disebut dalam ini karena telah diatur dalam UU No. 16 Tahun 2006 tentang SP3K. Pemahaman sebagian pihak bahwa penyuluhan pertanian tidak lagi menjadi urusan yang penting adalah suatu kekeliruan.

Kesejahteraan, keadilan dan kesetaraan merupakan tujuan penting dalam penyuluhan pertanian. Hal ini merupakan salah satu aspek sosial yang mempengaruhi kehidupan masyarakat dan petani. Sasaran kebijakan penyuluhan kepada sasaran utama dan sasaran antaran secara jelas dijabarkan dalam UU SP3K. Dengan adanya pedoman penyuluhan pertanian ini pedoman penyuluhan menjadi efisien dan terarah, akan tetapi dalam implementasi kebijakan sistem penyuluhan masih terdapat permasalahan, diantaranya kualitas dan jumlah penyuluh yang kurang, motivasi penyuluh serta sarana prasarana penyuluhan yang belum memadai.

Penulis menyarankan kepada pemerintah pusat untuk mempertimbangkan penambahan jumlah penyuluh pertanian sesuai dengan kondisi daerah-daerah di wilayah indonesia, baik itu penyuluh Pegawai Negeri Sipil atau penyuluh Tenaga Harian Lepas-Tenaga Bantu Penyuluh Pertanian (THL-TBPP). Sementara untuk pemerintah daerah melalui Dinas Pertanian, penulis menyarankan melibatkan penyuluh dalam penyusunan kegiatan bidang penyuluhan, melakukan koordinasi ketingkat provinsi dan pusat terkait dengan programprogram yang akan direncanakan agar seluruh aspek penyuluhan dapat diperhatikan sesuai dengan aturan, serta mengalokasikan dana untuk pengiriman penyuluh ke pelatihan atau diklat teknis agar pengetahuan penyuluh meningkat.

\section{REFERENSI}

Armstrong, M., dan Taylor, S. 2013. Handbook of Human Resource Management Practice. 13th Edition. by Kogan Page Limited. USA.

Badan pusat Statistik. 2010. Data sensus penduduk Indonesia.

Badan Pusat Statistik. 2016. Data luas lahan sawah.
Baloch, M.A., Thapa, G.B. 2017. Review of the agricultural extension modes and services with the focus to Balochistan, Pakistan. Journal of the Saudi Society of Agricultural Sciences.

Dwi Sadono. 2008. Pemberdayaan Petani: Paradigma Baru Penyuluhan Pertanian di Indonesia. Jurnal Penyuluhan Maret 2008, Vol. 4 No. 1. IPB. Bogor.

J.A. Coutts. 1995. Agricultural extension policy as a framework for change, European Journal of Agricultural Education and Extension, 2:1, 1727, DOI: $10.1080 / 13892249585300041$.

Pricylia et al. 2018. Potensi Pengembangan Sumber Daya Manusia Penyuluh Pertanian Di Kabupaten Sigi. J. Agroland 25 (1) :46-57, April 2018.

R. Haug. 1999. Some leading issues in international agricultural extension, a literature review, The Journal of Agricultural Education and Extension, 5:4, 263-274, DOI: $10.1080 / 13892249985300061$.

R. Hu et al. 2012. Effects of inclusive public agricultural extension service: Results from a policy reform experiment in western China. China Economic Review 23 (2012) 962-974.

R. Moyo, A. Salawu. 2018. A survey of communication effectiveness by agricultural extension in the Gweru district of Zimbabwe. Journal of Rural Studies 60 (2018) 32-42

Sattaka, P., et al. 2016. Agricultural extension services to foster production sustainability for food and cultural security of glutinous rice farmers in Vietnam, Kasetsart Journal of Social Sciences.

S.P. Marsh \& D.J. Pannel. 1999. Agricultural extension policy and practice in Australia: An overview, The Journal of Agricultural Education and Extension, 6:2, 83-91, DOI: 10.1080/13892249985300201.

Subejo. 2006. Penyuluhan Pertanian Indonesia Di Tengah Isu Desentralisasi, Privatisasi Dan Demokratisasi. Jurnal Penyuluhan Juni 2006, Vol. 2, No. 2. IPB. Bogor.

Sundari, et al. 2015. Peran Penyuluh Pertanian Terhadap Peningkatan Produksi Usahatani Di Kabupaten Pontianak. Jurnal Social Economic of Agriculture, Volume 4, Nomor 1, April 2015.

Syahyuti. 2014. Modernisasi Penyuluhan Pertanian Di Indonesia: Dukungan Undang-Undang Nomor 23 Tahun 2014 terhadap Eksistensi Kelembagaan Penyuluhan Pertanian di Daerah. Analisis Kebijakan Pertanian, Vol. 14 No. 2, Desember 2016: 83-96. 
Perkembangan Penyuluhan Pertanian Dalam Mendukung Pertumbuhan Pertanian Di Indonesia (Jufitra Vintarno, Yogi Suprayogi Sugandi, Josy Adiwisastra)

\section{Peraturan dan Perundang-undangan}

Peraturan Menteri Pertanian Republik Indonesia No. 03 Tahun 2018 Tentang Pedoman Penyelenggaraan Penyuluhan Pertanian

Undang-Undang Nomor 16 Tahun 2006 tentang Sistem Penyuluhan Pertanian, Perikanan, dan Kehutanan.

Undang-Undang No. 23 Tahun 2014 Tentang Pemerintah Daerah 